\title{
COMPARING NOTES: Cross-Campus Visits For Clinician DeVelopment
}

\author{
JAMES A. SONNE*
}

As law-school clinicians, we take pride in creating a dynamic learning environment where students from virtually any background or perspective can learn lawyering skills and judgment in and through supervised live-client representation. And among the central lessons we aim to teach and model is the collaborative, in-person development of a lawyer's professional identity-across the class, between instructor and student, and in partnership with others. By framing the practice and profession through peer-to-peer learning we broaden and deepen the experience for our students far beyond what an isolated project could offer, and, in so doing, instill in them an abiding appreciation for the benefits of such learning in their careers.

But do we do this for ourselves as clinical instructors? Indeed, if first-hand comparative learning on a continuing basis is such an essential professional norm, should we not also engage in it for our own work with students and clients? And even if some of us already do this, could we do more, or in a more deliberate, reflective, and comprehensive way? After all, surely none of us is above improving ourselves through the example of others. We are all works in progress.

No matter our current approach for enhancing our teaching through peer engagement, this essay shares a relatively straightforward yet innovative idea that a colleague recommended to me a few years ago: on-site visits to clinicians at other law schools. And although the suggestion was particularly salient to me as a new clinician building a new clinic at the time, it is one that can benefit any clinical teacher dedicated to self-improvement. Having taken the suggestion, I write to share the experience and its promise-for new and seasoned clinicians alike.

\section{The Need}

Collaborative learning is at once a core pedagogical method of clinical legal education and one of its fundamental learning goals. ${ }^{1}$ Whether in fieldwork, supervision, rounds, or seminar, we regularly urge our students to work together - in project teams, as a class, and as part of a broader collective. This approach allows students to combine forces with one another (and us) to provide optimal service to their clients. ${ }^{2}$ More to the point here, it introduces students to group dynamics in the practice, and the benefits of working with others; and not just in the project at hand but as part of an ongoing process of self-development. ${ }^{3}$

* Professor of Law at Stanford Law School and Director of its Religious Liberty Clinic.

1. Susan Bryant et al., Transforming the Education of Lawyers: The Theory and Practice of Clinical Pedagogy 23-25 (2014).

2. See David F. Chavkin, Clinical Legal Education 86 (2002) (emphasizing the practical benefits of collaboration).

3. See id. at 87 (on the value of collaboration as a professional skill and value); see also Susan Bryant, Collaboration in Law Practice: A Satisfying and Productive Process for a Diverse 
Lawyering is not done in a vacuum, but in the context of human relationships and the overlapping yet diverse frameworks of those who engage in the enterprise. An essential element of experiential learning, therefore, is the process of learning from, and with, the experiences of a larger professional community. ${ }^{4}$

Turning then to the development of clinicians, there are fortunately many opportunities for us to build such a community for ourselves. Among American law professors, we are arguably the most active, deliberate, and organized as a group. Our flagship effort is the Association of American Law Schools (AALS) Conference on Clinical Legal Education each spring, with its plenaries and breakouts, subcommittees, and other formal and informal ways to both share and learn about clinical teaching and scholarship. But there are additional peer-to-peer vehicles as well, including the AALS Annual Meeting for all law professors each winter; the fall Clinical Law Review workshop; gatherings hosted by the Clinical Legal Education Association or regional groups throughout the year; and an active online network. Truly, today's clinician does not want for professional support and inspiration outside her own school, and rightly so. ${ }^{5}$

Notwithstanding these invaluable opportunities, however, they are largely pursued at arm's length and tend to be static in that they focus almost exclusively on generalized topics or, at most, simulation-based discussion. This is by no means a criticism. Rather, it is only to point out that, for all their remarkable benefits, the dominant means of comparative learning for the clinical teacher do not - and, for practical and other reasons, likely could not-include the type of interactive experience we demand for students: on-site, real-time learning from others practicing their craft. Additionally-and unlike their podium-teaching counterparts - clinicians do not often have an opportunity to serve as visiting faculty given their many school-specific commitments. ${ }^{6}$ Apart from a serendipitous visit in connection with one of the conferences above, therefore, we rarely see — much less engage with — the actual teaching of our colleagues. ${ }^{7}$

Profession, 17 VT. L. REV. 459 (1993) (stressing the importance of law schools developing a collaborative pedagogy necessary for successful law practice).

4. In addition to the more particularized dynamics of clinical training, broader educational theory on the power of observational learning supports the attendant benefits of professional development in seeing others work. See Terrill Pollman, The Sincerest Form of Flattery: Examples and Model-Based Learning in the Classroom, 64 J. LEGAL EduC. 298, 313 (2014) (describing benefits of observational learning in the law-school context, including from peers).

5. See William M. Sullivan et al., Carnegie Foundation for the Advancement of Teaching, Educating Lawyers: Preparation for the Profession of Law 201 (2007) [hereinafter CARNEGIE REPORT] (emphasizing the importance of community for law teachers in a process of pedagogical self-awareness and renewal).

6. See Philip C. Kissam, Lurching Towards the Millennium: The Law School, the Research University, and the Professional Reforms of Legal Education, 60 Онго Sт. L.J. 1965, 1997 (1990) (observing that "rather extreme time demands are placed on clinical faculty because of their need to supervise many students, publish as well as teach, and manage what in effect are small or medium-size law firms").

7. A notable exception to cross-institutional isolation can be found in international outreach 
If we clinicians are nonetheless committed to intentional and sustained peer learning as a professional norm - and we surely are - the friendly amendment of hands-on comparative visits would seem a promising complement to other crossinstitutional opportunities as a clinic community. ${ }^{8}$ There are, of course, challenges to the effort; including, most notably, time and money. But it is an idea that should be explored, and on both visiting and hosting sides. My own story illustrates why.

\section{The Idea}

Six years ago, I left private practice to become the founding director of a pilot clinic focusing on religious-liberty litigation. At the time, it was the nation's only law-school clinic on that subject and, given some of the broader controversies in the area, a cause of significant media and wider public interest. ${ }^{9}$ On one level, I welcomed this spotlight to the extent it helped draw students, market our services to clients who needed our help, and elevate a vision of religious liberty as a universal right that is fundamental to a flourishing and welcoming society. Despite this focus on us as a new and needed venture, however, I wanted to build the clinic according to established pedagogical practices, given that our immediate purpose was - and remains - to prepare students of all backgrounds and perspectives to be lawyers in any field. Moreover, as a former big-firm lawyer with some experience in podium teaching but none as a clinician, building on a time-tested model was arguably as important to my success as it was to the clinic's.

From the start of the new program, therefore, I consulted at length the experienced clinical faculty on campus - including reciprocal seminar and caserounds visits, syllabus reviews, on-site workshops, and in-person meetings. These efforts were indispensable. In many ways, they sparked the clinic's founding pedagogical approach, which is rooted in both a particularized understanding of the unique clinical system at our school - one of the few clinical programs in the country where students participate on a full-time basis in a given academic term - as well as the informed wisdom these colleagues shared with me. Across our eleven-subject program is a remarkably diverse, talented, and accomplished group of teachers, scholars, and lawyers. It was a blessing to have joined such an exceptional professional team.

In addition to the insights of colleagues in house, I also utilized the broader resources described above, including regular attendance, networking, and small-

across clinics. See, e.g., The Global Clinical Movement: Educating Lawyers for Social JustiCE (Frank S. Bloch ed., 2011) (describing clinical approaches across the world, including cross-cutting and collaborative efforts).

8. See CARnEgie RePORT, supra note 5, at 201 (emphasizing generally the value of sharing pedagogical self-reflections among one's peers as a community of law faculty).

9. See, e.g., Ethan Bronner, At Stanford Law School, a Unique Clinic Offers Training in Religious-Liberty Cases, N.Y. TIMES, Jan. 22, 2013, at A16 (hailing our clinic as a (potentially controversial) milestone in clinical education). 
group facilitation at the AALS clinical and general conferences; participation in the fall Clinical Law Review workshops; and an active role in regional gatherings. In connection with the experience of writing a clinical law-review article for the first time, I further explored the pedagogical literature and took part in various online discussion forums about clinical teaching, client service, and social justice. $^{10}$

Notwithstanding all of these measures, however, my early understanding of the clinical undertaking still felt lacking in some ways, as my prior practice and lecture-driven teaching approaches, coupled with a slightly policy-heavy view of the project, seemed to predominate. Then in the clinic's second year, a faculty colleague and friend who had just visited one of our seminar classes proposed the idea of in-person visits with leading clinicians at other institutions. In her view, although our clinic had the practical and substantive ingredients of a first-rate program-including many elements drawn from my past professional experience as well as the promise of a rich, dynamic subject - it could transform into an even stronger whole with an enhanced pedagogical directive through the wider clinical world. $^{11}$

Beyond the immensely helpful contributions of those on site, as well as conference and book learning, my colleague urged a broader comparative process to truly develop the pilot project into an established clinical offering. Having since secured that status - we are now a permanent and celebrated part of our school's clinical program - there is no doubt she was right.

\section{The Experience}

My first off-site journey was a day-long visit four years ago to one of the nation's foremost experts on clinical pedagogy, and whose Washington, D.C. law school boasts one of the premier clinical programs in the country. The trip was arranged by my clinical dean; the visited clinician and I had never met before. Our schedule that day-which my host, and now friend, graciously put together-included a tour of the law school and clinic space; a morning seminar and afternoon case-rounds session; individual office meetings with two of my host's colleagues; and an in-depth reflective lunch and closing coffee. Notably, the classroom sessions were for two clinics that were outside my field-domestic violence, and women and the law - and although my host and her two colleagues engaged in various civil-rights litigation efforts in their teaching and practices, their substantive focuses were likewise distinct from mine.

Not long after this first trip, a second cross-campus effort involved a series of half-day visits to three other leading clinicians at separate schools in and

10. See generally James A. Sonne, Religious Liberty, Clinical Education, and the Art of Building Bridges, 22 CliniCAL L. REV. 251 (2015) (providing comprehensive overview of our clinic's work and pedagogy).

11. See William P. Quigley, Introduction to Clinical Teaching for the New Clinical Law Professor: A View from the First Floor, 28 AKRON L. REV. 463, 463-65 (1995) (stressing the need for veteran advice to new clinicians). 
around New York City. My dean again helped arrange the first of these visits, while I set up the other two based on a now-growing experience with the concept. As in Washington, although each of the New York clinicians taught and litigated in the civil-rights arena generally, they focused in different substantive areas, from both me and one another-including racial justice, gay rights, and immigration. Also similar to the first expedition, the itinerary across these three schools included office meetings, tours, and visits to class sessions - and, in one case, even a reflective subway ride through part of the city.

Third and finally, my latest off-site visit occurred this past fall when I spent the day with a prominent New England clinician I had met earlier that year at the AALS Clinical Conference. Unlike the prior visits, which had largely taken place on campus, this one included not only in-depth office meetings and classroom sessions but field observation as well. Specifically, my host's housing clinic includes a module where students provide same-day counseling and advocacy to clients facing foreclosure who are invited by the court to use the clinic's services on that limited basis. In the morning, I watched the students in action with, and for, their clients; in the afternoon, I joined a reflective class debrief. The visit also provided me the chance to sit in on a strategy session for a policy project that the clinician and a past student were spearheading.

\section{The Fruit}

The three off-site trips taught me a great deal that could have come only from making the effort. At a basic level, there was the experience of seeing clinical teaching and practice in different spaces. In preparing practice-ready and clientready students, environment indeed makes a difference. ${ }^{12}$ More universally, there was the range of teaching techniques and styles - and on a variety of topics across many and diverse groups of students - that were nonetheless rooted in shared clinical themes of client-centeredness, cross-cultural literacy, and reflective lawyering. ${ }^{13}$ Also on display across the visits was how various docket and syllabus choices were realized in context; how different case projects were staffed and supervised; and how faculty, students, and even clients, viewed the clinical enterprise - specifically and globally.

12. See Roy Stuckey et al., Best Practices for Legal Education: A Vision and a ROADMAP 197 (2007) (including the need for appropriate professional space as a best practice for experiential education); see also Ruth Anne Robbins, Law School Grads Should Be "Client Ready, "NAT'L L.J., Feb. 18, 2013, at 31 (arguing that graduating law students should not only be "practice ready" but "client ready" as well).

13. See generally DAVID A. Binder et Al., Lawyers as Counselors (2d ed. 2004) (providing signature treatment of client-centered lawyering as a core element of clinical legal education); Susan Bryant \& Jean Koh Peters, The Five Habits: Building Cross-Cultural Competence in Lawyers, 8 CLINICAL L. REV. 33 (2001) (providing leading framework for developing the skill and value of cross-cultural competence for aspiring (and seasoned) lawyers); see also Anthony G. Amsterdam, Clinical Legal Education-A 21st-Century Perspective, $34 \mathrm{~J}$. LEGAL EDUC. 612, 616 (1984) (urging reflective "techniques of learning from experience"). 
And throughout it all, there was the unique opportunity to engage in a timely dialogue with each clinician on what they were doing and why, and in a way detached from the pressure of personal performance - for visitor or host - that might otherwise accompany an in-house class visit — particularly for junior faculty in the midst of retention and promotion processes. ${ }^{14}$ On a related note, it also helped to see in the work of others many of the things I was already doing well, which was reassuring as a new clinician and helped me build from a place of confidence on my return to campus. ${ }^{15}$

Once home, the lessons of each visit took shape in various and concrete ways. In the classroom, I revamped the syllabus to focus more on clinical themes and less on legal doctrine; adding, for example, both a cross-cultural exercise and mediation simulation from the first two trips and a debrief reflection from the third, while reducing substantive readings on matters the students largely pick up in the course of their fieldwork anyway. I also adjusted the docket to prioritize opportunities for unified learning across the class - which was a regular theme in the visits - in place of a less cohesive approach that had seemed more driven by a practice-heavy perspective and somewhat skewed conception of the project, which, on reflection, appeared to lack the structure necessary for optimizing deep learning and transfer. And in both supervision and case rounds, I tempered a tendency toward direct instruction that had stemmed from my years in practice and podium teaching in favor of a series of non-directive methods that my visit hosts had exhibited and shared with me. ${ }^{16}$

From these lessons and changes, the clinic has undoubtedly improved. Student and alumni feedback, for example, shows that the increased focus on shared learning across the class has in fact deepened the experience and enhanced transferrable learning. Similarly, the move to prefer project-based professional development over substantive legal doctrine has expanded our clinic's reach — on those norms to be sure but, frankly, on substance as well, given a more contextualized and human-first approach - to more and diverse students. And perhaps not coincidentally, applications to the clinic have grown every year and exponentially since its founding. Finally, and most importantly on a wider institutional and personal level, the off-site visits enhanced teaching and scholarship efforts that led to our elevation from a pilot project to a full-fledged

14. See Donald A. Schön, Educating the Reflective Practitioner: Toward a New Design for TeAching AND LEARNINg IN THE Professions 311 (1987) (resisting an academic's typical career pressures in favor of reflective practice); see also Robert J. Condlin, Learning from Colleagues: A Case Study in the Relationship Between "Academic" and "Ecological" Clinical Legal Education, 3 CliniCAL L. Rev. 337, 345-46 (1997) (emphasizing the value of detached collaborative reflection in the broader lawyering setting).

15. See Martine A. H. Braaksma et al., Observational Learning and the Effect of ModelObserver Similarity, 94 J. EdUC. PSYCHOL. 405, 405 (2002) (describing confidence-building among the fruits of observational learning).

16. See Philip G. Schrag, Constructing a Clinic, 3 Clinical L. Rev. 175, 178 (1996) (emphasizing that "planning a clinic cannot be static," but "must respond to experience and to changed circumstances"). 
member of the school's permanent clinical program - a milestone for any clinic, but one with particular meaning for us given our pathbreaking area of focus. ${ }^{17}$

\section{The Transfer}

To be sure, my experience was somewhat unique as a new clinician in a relatively novel start-up setting. But there is no reason to think off-site visits could not offer similar professional-development benefits to other clinicians - both new and seasoned alike, and regardless of subject area. Whether in the ongoing process of syllabus or docket development, refinement of discussion or supervision techniques, enhancement of cross-cultural methods, or even in the gathering of ideas for engaging the current generation on contemporary issues of the day, there is so much we can learn from one another. If nothing else, the mere discipline of stepping outside one's self and seeing the profession through the eyes of another - if only for a few hours - can bring reflective lessons and renewed energy and deliberateness to any clinician's work. ${ }^{18}$

The proposal is not without its challenges, but the three that come most readily to mind can be overcome. First, there is cost. These visits, however, need not include long-distance flights, and can likely be done in connection with other travel in any event; in two of my trips, I had other work engagements nearby and, with a little flexibility from those involved, was able to combine things. A second issue might be the time involved. But again, the trips were well worth the effort to me as the visitor. And although my experience was limited to that side of the ledger, not only has each host shared with me how positive it was for them, too, the collegial spirit of the clinic community is one of its hallmarks and was on full display in the gracious responses from each host to the request for a visit-which, for most of them, was the first time we met. ${ }^{19}$

Third, and finally, there is the matter of confidentiality; after all, in-time observation might include exposure to privileged or other types of private client information. But these sensitivities can be protected with a basic consulting or

17. See Rick Schmitt, Stanford Law School Religious Liberty Clinic, STAN. LAw., Dec. 1, 2018, at 30 (alumni magazine feature on our clinic and the student experience it offers).

18. See BRYAnT ET AL., supra note 1, at 25 (insisting that "[t]he most important human dimension of practice involves seeing the world from another's perspective").

19. Although my experience benefited from pre-existing relationships, surely the norms of faculty development prevailing at most schools and encouraged by ABA Standard 403 (and its Interpretation 403-1) would encourage outreach and cooperation across campuses. Indeed, the landmark Carnegie Report urges as its closing recommendation that law schools "work together, within and across institutions." CARNEGIE REPORT, supra note 5, at 10 (emphasis added). Moreover, the fact that clinicians also serve clients urges comparative learning all the more. See Condlin, supra note 14, at 346 ("Since there is a professional obligation to work competently for clients, being able to draw out and run with others' insights and experiences is not an optional or inconsequential practice skill. It is an essential component of professional practice.”). 
similar agreement. ${ }^{20}$ And even if such an arrangement were somehow infeasible, a comparative visit would still be worth it if only for the sit-down colleague meetings, student conversations, public fieldwork, and in-class simulations or other non-client events that can be experienced.

\section{Conclusion}

As the clinical pioneer Gary Bellow once urged, "[p]art of clinical education has to involve teaching lawyers how to learn from each other." ${ }^{21}$ So it must be with clinical educators as well. And not only in the many conferences and other comparative-learning opportunities we already value, but also in visiting one another where we do the work we all love so much. My experience testifies to that idea's benefits, and hopefully will inspire others to seek them out.

20. See Bryan L. Adamson et al., Clinical Faculty in the Legal Academy: Hiring, Promotion and Retention, 62 J. LEGAL EDUC. 115, 154 (2012) (urging use of confidentiality agreements and conflicts checks for clinic visitors).

21. Jeanne Charn, Service and Learning: Reflections on Three Decades of the Lawyering Process at Harvard Law School, 10 CliniCAL L. Rev. 75, 78 (2003) (quoting Gary Bellow). 